\title{
Perancangan Sistem Informasi Akademik Siswa menggunakan Code Igniter 3 di SMKN 4 Payakumbuh
}

\author{
Zeki Marzuki $^{1^{*}}$, Hari Anton Musril ${ }^{2}$ \\ ${ }^{1,2}$ Program Studi Pendidikan Teknik Informatika dan Komputer, Fakultas Tarbiyah dan Ilmu Keguruan, IAIN Bukittinggi \\ ${ }^{1}$ zekimarzuki@gmail.com*, ${ }^{2}$ hariantonimusril@gmail.com \\ *corresponding author
}

\begin{tabular}{|c|c|}
\hline ABSTRACT & Article Info \\
\hline $\begin{array}{l}\text { In its implementation, the academic system that runs at SMKN } 4 \text { Payakumbuh is } \\
\text { deemed not optimal; this is because the system used is still manual. With these } \\
\text { problems, various problems arise, especially in the assessment process, } \\
\text { attendance, and information about student development to parents. For that, we } \\
\text { need an information system that is able to support decision-making in obtaining } \\
\text { information on academic activities at SMKN } 4 \text { Payakumbuh. The making of this } \\
\text { academic information system uses a Codeigniter } 3 \text { framework, while the research } \\
\text { method used is }(R \& D) \text {. The model used is the } 4 D \text { version by applying the } \\
\text { waterfall model. Based on the results of the research conducted, the researcher } \\
\text { succeeded in creating an academic information system for students at SMKN } 4 \\
\text { Payakumbuh. The results of the validity test conducted by a computer expert on } \\
\text { this product get a value of } 0.89 \text { which is very good. The practical test results } \\
\text { were carried out by curriculum representatives with a value of } 1.0 \text {, which is very } \\
\text { practical. And the results of the effectiveness test with the homeroom teacher and } \\
\text { students with a value of } 0.98 \text { are very good. }\end{array}$ & $\begin{array}{r}\text { Article history } \\
\text { Received: Jan. } 2^{\text {nd }}, 2021 \\
\text { Revised: May } 8^{\text {th }}, 2021 \\
\text { Accepted: May } 30^{\text {th }}, 2021 \\
\text { Keywords } \\
\text { student academic, } \\
\text { information system, } \\
\text { codeigniter, } \\
\text { 4D version } R \& D, \\
\text { waterfall. }\end{array}$ \\
\hline ABSTRAK & \\
\hline $\begin{array}{l}\text { Dalam pelaksanaannya, sistem akademik yang berjalan di SMKN } 4 \text { Payakumbuh } \\
\text { dirasa belum optimal, hal ini dikarenakan sistem yang digunakan masih bersifat } \\
\text { manual. Dengan permasalahan tersebut maka muncul berbagai permasalahan } \\
\text { terutama pada proses penilaian, absensi serta informasi mengenai perkembangan } \\
\text { siswa kepada orang tua. Untuk itu, diperlukan suatu sistem informasi yang } \\
\text { mampu mendukung pengambilan keputusan dalam memperoleh informasi } \\
\text { kegiatan akademik di SMKN } 4 \text { Payakumbuh. Pembuatan sistem informasi } \\
\text { akademik ini menggunakan framework Codeigniter 3, sedangkan metode } \\
\text { penelitian yang digunakan adalah (R\&D). Model yang digunakan adalah versi } 4 \mathrm{D} \\
\text { dengan menerapkan model waterfall. Berdasarkan hasil penelitian yang } \\
\text { dilakukan peneliti berhasil menciptakan sebuah sistem informasi akademik siswa } \\
\text { di SMKN } 4 \text { Payakumbuh. Hasil uji validitas yang dilakukan oleh ahli komputer } \\
\text { produk ini mendapatkan nilai } 0,89 \text { yaitu sangat baik. Hasil uji praktis dilakukan } \\
\text { oleh wakil kurikulum dengan nilai } 1,0 \text { yaitu sangat praktis. Dan hasil uji } \\
\text { efektifitas dengan wali kelas dan siswa dengan nilai } 0,98 \text { yaitu sangat baik. }\end{array}$ & \\
\hline
\end{tabular}




\section{PENDAHULUAN}

Kemajuan teknologi adalah sesuatu yang tidak bisa dihindari dalam kehidupan ini, karena kemajuan teknologi akan berjalan sesuai dengan kemajuan ilmu pengetahuan. Setiap inovasi diciptakan untuk memberikan manfaat positif bagi kehidupan manusia. Teknologi juga memberikan banyak kemudahan, serta sebagai cara baru dalam melakukan aktivitas manusia, dan mempermudah memperoleh informasi yang tetap dan akurat, baik secara langsung maupun secara tidak langsung. Manusia juga sudah menikmati banyak manfaat yang dibawa oleh inovasi-inovasi teknologi yang telah dihasilkan dalam dekade terakhir ini, termasuk di segala aspek kehidupan dan pendidikan. Perencanaan pembelajaran yang baik akan melahirkan proses pembelajaran yang baik juga, demikian pula dengan sistem akademik sekolah tersebut. Setelah pelaksanaan pembelajaran selesai, langkah selanjutnya yang wajib dilakukan guru ialah mengadakan penilaian. Penilaian diartikan sebagai proses, cara, atau pembuatan nilai. Nilai dapat berupa angka maupun deskripsi yang diberikan untuk mengetahui kualitas suatu produk tertentu. Bila dihubungkan dalam dunia pendidikan, nilai digunakan untuk mengukur kemampuan peserta didik dalam mengikuti kegiatan pembelajaran.

SMKN 4 Payakumbuh merupakan salah satu sekolah di Kota Payakumbuh yang aktif dalam pemanfaatan teknologi informasi baik dalam kegiatan belajar mengajar maupun pada proses administrasi sekolah. Guru dalam proses kegiatan pengambilan keputusan tentang pencapaian pembelajaran peserta didik berdasarkan kompetensi dasar setelah peserta didik itu mengikuti proses pembelajaran. Di SMKN 4 Payakumbuh data yang diperoleh pendidik selama pembelajaran berlangsung disaring dan dikumpulkan melalui prosedur dan alat penilaian yang sesuai dengan kompetensi dasar atau indikator yang akan dinilai, dari proses ini diperoleh potret/profil kemampuan peserta didik dalam mencapai sejumlah standar kompetensi dan kompetensi dasar yang dirumuskan dalam Kurikulum yang berlaku. Data tersebut diperlukan sebagai informasi yang diandalkan sebagai dasar pengambilan keputusan.

SMKN 4 Payakumbuh belum memiliki sistem informasi akademik siswa yang sesuai dengan kurikulum yang berlaku untuk membantu dalam penyusunan rapor siswa. Hal ini menyebabkan masih adanya beberapa kekurangan dalam kegiatan penyusunan rapor seperti kurang efektifnya pekerjaan, lambatnya proses penyusunan, hingga banyaknya waktu dan biaya yang dibutuhkan. Sehingga sekolah tersebut membutuhkan sistem informasi akademik yang mendukung kurikulum yang berlaku. Di SMKN 4 Payakumbuh terdapat 3 jurusan yaitu Teknik Komputer \& Jaringan, Multimedia, dan Rekayasa Perangkat Lunak. Pada masing-masing jurusan yang terdapat tersebut dibagi beberapa kelas sesuai jumlah dan kapasitas yang dibutuhkan. Pada tahun akademik 2019/2020 ini total keselurahan peserta didik berjumlah 621 orang, terdiri dari laki-laki dan perempuan. Dari total jumlah peserta didik di SMKN 4 Payakumbuh jika masih menggunakan sistem manual maka akan terjadi banyak permasalahan. Dengan demikian maka untuk meminimalisir terjadinya permasalahan tersebut maka diperlukan sebuah sistem informasi akademik siswa yang berbasis online dan menggunakan database.

Berdasarkan wawancara yang dilakukan pada tanggal 8 Januari 2020 dengan Wakil Kurikulum ibu Nazwita, S.Kom., M.Kom. di SMKN 4 Payakumbuh beliau menyampaikan sekolah belum memiliki sistem informasi akademik yang berupa rapor online, nilai Ulangan Harian (UH) siswa, rekap kehadiran, dan rekap pelanggaran siswa. Di SMKN 4 Payakumbuh masih menerapkan rekap kehadiran dan pelanggaran siswa secara manual, sehingga data-data tersebut sering hilang, membuat guru susah untuk merekap data kehadiran dan pelanggaran siswa selama satu semester. Untuk penilaian rapor menggunakan aplikasi rapor kurikulum 2013 menggunakan Microsoft Excel. Dengan aplikasi 
ini wali kelas mengalami kendala seperti, terdelete. Bila ter-delete rumusnya, semua nilai yang sudah diinput akan hilang dan hasilnya akan false, ini beresiko untuk penilaian berikutnya. Guru harus menggandakan lagi pada aplikasi yang aslinya, ini akan menjadi pekerjaan rumit bagi guru. Guru juga mengalami kendala lain berupa pengisian data deskripsi pengetahuan dan keterampilan selama satu semester, karena deskripsi pengetahuan dan keterampilan akan berbeda-beda setiap siswa. Aplikasi rapor kurikulum 2013 atau Microsoft Excel ini memiliki kelemahankelemahan. Kelemahan-kelemahan tersebut diantaranya yaitu belum adanya database yang valid, terjadinya redundansi data dan tidak online ke internet sehingga membutuhkan waktu yang lama dalam mengetahui hasil yang diperoleh, kerena tidak disimpan online di server dan data sering hilang.

Berdasarkan uraian di atas, peneliti dapat memberikan solusi untuk meminimalisir permasalahan tersebut dengan sebuah sistem informasi. Sistem informasi akademik ini menggunakan Codeigniter 3 dan PHP, yang memberikan kemudahan bagi wali kelas dan orang tuanya dalam melihat informasi akademik siswa. Kemudian dalam mengolah database-nya menggunakan MySQL. Dengan sistem informasi akademik ini diharapkan mampu meningkatkan kualitas administrasi pendidikan, meningkatkan efisiensi waktu dan sumber daya bagi sekolah baik dalam kegiatan belajar mengajar maupun administrasi sekolah seperti pengisian rapor online, rekap kehadiran siswa dan rekap pelanggaran siswa. Selain bermanfaat untuk sekolah sistem informasi ini juga bermanfaat untuk orangtua dan siswa.

\section{METODE}

Jenis penelitian yang digunakan adalah Penelitian dan Pengembangan (Research and Development). Research and Development adalah penelitian yang digunakan untuk menghasilkan produk tertentu, dan menguji keefektifan produk tersebut. R\&D (Research and Deevelopment), merupakan metode penelitian yang digunakan untuk mengembangkan atau memvalidasi produkproduk yang digunakan dalam pendidikan dan pembelajaran.

Langkah-langkah Penelitian Research and Development yang peneliti terapkan adalah versi 4-D (Four D) seperti terlihat pada Gambar 1. Thiagrajan mengemukakan bahwa, langkahlangkah penelitian dan pengembangan disingkat dengan 4-D (Four D), yang merupakan perpanjangan dari Define-Design-DevelopDisseminate.

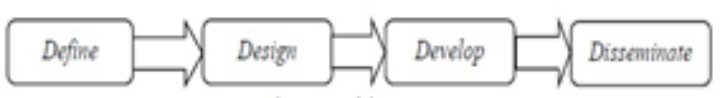

Gambar 1. Pengembangan Model 4D

Dalam melaksanakan penelitian, peneliti mengikuti beberapa proses atau tahapan yang ada pada gambar 1. Pengembangan model 4D, peneliti merincikan yaitu:

1. Define, pada tahap ini yaitu mencari informasi sistem yang sedang berjalan, sehingga memudahkan peneliti dalam menerjemahkan masalah yang timbul dalam perancangan sistem informasi. Peneliti harus mengetahui masalah apa yang dihadapi oleh wali kelas, tata usaha dan wakil kurikulum dalam proses penilaian siswa dan data akademik siswa. Di SMKN 4 Payakumbuh masih menerapkan rekap kehadiran dan pelanggaran siswa secara manual, sehingga data-data tersebut sering hilang, membuat guru susah untuk merekap data kehadiran dan pelanggaran siswa selama satu semester. Untuk penilaian rapor menggunakan aplikasi rapor kurikulum 2013 menggunakan Microsoft Excel. Dengan aplikasi ini wali kelas mengalami kendala seperti, ter-delete. Bila ter-delete rumusnya, semua nilai yang sudah diinput akan hilang kebelakang hasilnya akan false, ini beresiko untuk penilaian berikutnya. Guru harus mengkopi lagi pada aplikasi yang aslinya, ini akan menjadi pekerjaan rumit bagi guru. Guru juga mengalami kendala lain berupa 
pengisian data deskripsi pengetahuan dan keterampilan selama satu semester, karena deskripsi pengetahuan dan keterampilan akan berbeda-beda setiap siswa. Aplikasi rapor kurikulum 2013 atau Microsoft Excel ini memiliki kelemahan-kelemahan. Kelemahan-kelemahan tersebut diantaranya yaitu belum adanya database yang valid, terjadinya redundansi data dan tidak online ke internet sehingga membutuhkan waktu yang lama dalam mengetahui hasil yang diperoleh, kerena tidak disimpan online di sever dan data sering hilangg. Studi literatur yang peneliti lakukan yaitu mencari referensi mengenai codeigniter 3, teori sistem informasi, teori database, dan teori akademik siswa. Peneliti juga melakukan studi literatur mengenai kebijakan akademik siswa di SMKN 4 Payakumbuh.

2. Design, pada tahap ini peneliti merancang sebuah sistem informasi berdasarkan kebutuhan dari sekolah untuk memudahkan pegawai tata usaha, wali kelas dan wakil kurikulum dalam pengelolaan nilai-nilai siswa. Desain alur sistem wali yaitu terdiri dari menu login tampilan wali kelas, tampilan beranda/halaman awal, kehadiran, penilaian, pelanggaran, panduan dan logout. Pada menu kehadiran terdapat sub menu entry kehadiran, dimana sub menu ini berfungsi untuk menginput kehadiran siswa oleh wali kelasnya masing-masing dan akan tersimpan ke sub menu rekap kehadiran, sub menu rekap kehadiran ini akan tampil pada rapor siswa tersebut untuk merekap kehadirannya selama proses pembelajaran. Selanjutnya pada menu penilaian terdapat sub menu input nilai siswa, sub menu ini bertujuan untuk memberikan penilaian pada siswa, dimana nilai ini sudah nilai kesuluruhan yang diterima wali kelas dari masing-masing guru mata pelajaran, setelah nilai diinputkan maka bisa dilanjutkan ke tahap percetakan nilai rapor siswa. Selanjutnya pada menu pelanggaran terdapat juga sub menu input nilai pelanggaran, disini wali kelas juga menginputkan nilai pelanggaran siswa yang melakukan pelanggaran dan bagi siswa yang telah diproses maka pelanggaran yang dilakukannya bisa dilihat laporannya dan dicetak pada pilihan cetak pelanggaran. Selanjutnya desain alur sistem user (siswa/orang tua) yaitu terdiri dari menu login tampilan User (siswa/orangtua)/ halaman menu, biodata, rapor, pelanggaran, panduan dan logout. Pada menu biodata siswa bisa melakukan perbaikan datanya jika datanya belum lengkapi. Selanjutnya pada menu rapor siswa bisa melihat dan mencetak rapornya dan dilanjutkan pada menu pelanggaran siswa yang bersangkutan melakukan pelanggaran selama proses pembelajaran juga bisa melihat dan mencetak laporan pelanggarannya, selanjutnya siswa logout dari sistem.

3. Develop, dalam tahap ini penulis melakukan pengembangan aplikasi dengan menggunakan model pengembangan waterfall model, yaitu:

1) Communication, pada tahap ini, peneliti melakukan kegiatan wawancara ke lokasi penelitian.

2) Planning, tahapan planning merupakan langkah untuk menentukan perencanaan yang menjelaskan tentang estimasi tugastugas teknis yang akan dilakukan, resikoresiko yang dapat terjadi, sumber daya yang diperlukan dalam membuat sistem, produk kerja yang ingin dihasilkan, penjadwalan kerja yang akan dilaksanakan, dan tracking proses pengerjaan sistem (pengerjaan mengikuti jalan/tahapan). Pada tahap ini user mempunyai tugas yaitu mendaftarkan data kepada admin, login dan merubah data serta melengkapi data yang kurang jika diperlukan. Dan selanjutnya tugas wali kelas yaitu login ke sistem, menambahkan, merubah, menghapus indikator penilaian dan item penilaian, rekap absensi serta pelanggaran siswa dan menambahkan data siswa maupun melihat data siswa yang sudah dilengkapi 
oleh siswa tersebut. Sistem informasi ini dirancang kurang lebih satu bulan yaitu bulan juni 2020.

3) Modeling, struktur data pada pembuatan dan perancangan sistem peneliti menggunakan framework Codeigniter 3 dan framework css (font-end) Bootstrap4.

4) Construction, tahapan ini merupakan proses penerjemahan bentuk desain menjadi kode atau bentuk bahasa yang bisa dikenali oleh komputer/mesin. Setelah pengkodean selesai, dilakukan pengujian terhadap sistem dan juga kode yang sudah dibuat. Tujuannya untuk menemukan kesalahan (error) sehingga bisa diperbaiki. Pengujian menggunakan black box testing.

5) Deployment, tahapan ini merupakan tahapan implementasi software ke customer, perbaikan software, evaluasi software, dan pengembangan software berdasarkan umpan balik yang diberikan agar sistem dapat tetap berjalan dan berkembang sesuai dengan fungsinya.

4. Disseminate, proses diseminasi merupakan suatu tahap akhir pengembangan. Tahap diseminasi dilakukan untuk mempromosikan produk pengembangan agar diterima pengguna, baik individu, suatu kelompok, ataupun sistem. Tahapan diseminasi merupakan tahap penggunaan produk final yang dihasilkan barupa sistem informasi akademik siswa online yang bisa diakses di web browser. Dalam penyebaran penelitian ini hanya menggunakan group WhatsApp siswa SMKN 4 Payakumbuh yang digunakan oleh siswa SMKN 4 Payakumbuh serta guru dan pegawai SMKN 4 Payakumbuh. Untuk mengetahui produk ini bisa dilihat pada link https://sisfosmk.orbitiainbkt.com/ seperti gambar 2.

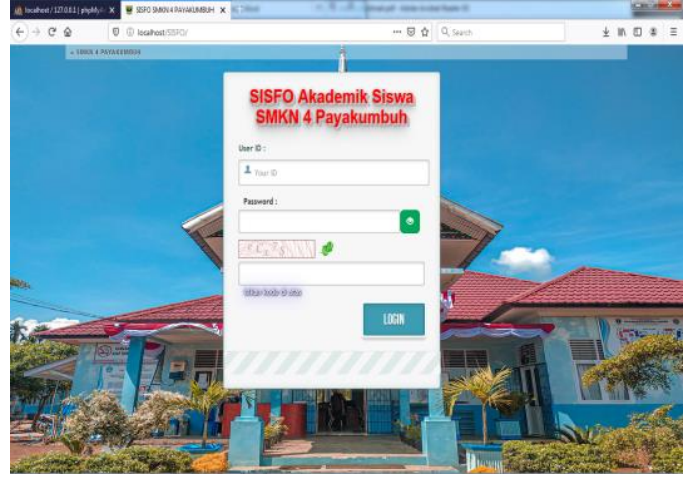

Gambar 2. Tampilan Web Sistem Informasi Akademik Siswa

Kevalidan, kepraktisan dan keefektivan penggunaan sistem informasi akademik siswa ini dengan cara memperhatikan produk, sehingga guru, wali kelas, siswa/orangtua dapat memberikan saran atau komentar untuk melengkapi pengembangan produk yang dihasilkan.

\section{HASIL DAN PEMBAHASAN}

Sistem informasi merupakan suatu sistem dalam suatu organisasi untuk mempertemukan kebutuhan pengolahan transaksi harian, mendukung operasi, bersifat manajerial dan kegiatan strategi dari suatu organisasi dan menyediakan pihak luar tertentu dengan laporan-laporan yang diperlukan.

Hasil dari penelitian ini adalah sebuah sistem informasi database akademik siswa menggunakan bahasa pemrograman PHP/MySql dengan Codeigniter sebagai web platform dari sistem informasi tersebut. Sistem informasi ini bisa diakses pada alamat https://sisfosmk.orbitiainbkt.com/. Sistem informasi ini mampu melakukan penambahan data, pengubahan data, penghapusan data, mengisi data pelanggaran siswa dan serta menampilkan hasil rapor siswa selama pencapaian belajarnya di SMKN 4 Payakumbuh. 
Sistem ini juga mampu memfilter data siswa berdasarkan nomor urutnya.

Peneliti telah melakukan Tahap pengujian Hasil Validitas dari aplikasi
Produk Kreatif dan Kewirausahaan (PKK) berbasis android ini yang dilakukan oleh 3 orang dosen ahli.

Tabel 1. Hasil Nilai Validitas

\begin{tabular}{llcc}
\hline No & \multicolumn{1}{c}{ Nama Dosen Penguji } & Nilai Rata-rata & Keterangan \\
\hline 1 & Gusnita Darmawati, S.Pd. & 0,93 & Sangat Baik \\
2 & Sarwo Derta, S.S., M.Kom. & 1.0 & Sangat Baik \\
3 & Dr. Supratman Zakir, M.Pd., M.Kom. & 0,89 & Baik \\
\hline
\end{tabular}

Hasil penilaian validitas dari 3 orang dosen ahli yaitu Gusnita Darmawati, S.Pd. dengan nilai 0,93, bapak Sarwo Derta, S.S., M.Kom. dengan nilai 1,0 dan bapak Dr. Supratman Zakir, M.Pd., M.Kom. dengan nilai 0,76, mendapatkan nilai akhir 0,89 , Maka nilai dari Sistem informasi akademik siswa ini dinyatakan sangat valid.

Hasil uji kepraktisan produk penelitian ditujukan kepada wakil kurikulum SMK N 4 Payakumbuh. Setelah melakukan proses perhitungan lembar kepraktisan dari guru yaitu Nazwita, S. Kom. dengan nilai 1,0, didapatkan nilai akhir 1,0 setelah diterapkan menggunakan moment kappa,

Rerata $=\frac{\text { jumlah total nilai kappa }(k)}{\text { jumlah banyak orang }}$

Rerata $=\frac{1}{1}=1$

Nilai kepraktisan tersebut berada pada Interval 0,81 - 1,00 dengan kategori sangat tinggi.

Untuk uji efektivitas produk ditujukan kepada lima orang siswa yaitu Nurul habibah, Moh jeki abdullah, Dina widia sari, M. ferdi dan Annisa rahmawati. Setelah melakukan proses perhitungan lembar efektivitas dari lima orang siswa, didapat nilai akhir 0,98 .

\section{SIMPULAN}

Dari hasil analisa dan perancangan, maka dapat disimpulkan bahwa:

1. Dengan adanya Sistem Informasi Akademik Siswa di SMKN 4 Payakumbuh ini, menghilangkan kesulitan dalam pengelolaan data siswa, guru, nilai siswa, pencarian data siswa, guru, dan pelanggaran yang dilakukan siswa.

2. Dengan adanya Sistem Informasi Akdemik Siswa di SMKN 4 Payakumbuh yang sudah terintegrasi ini, diharapkan pengkoordinasian informasi akademik khususnya di bagian kesiswaan, kurikulim, dan BP dapat dilakukan dengan cepat tanpa adanya ketidak konsistenan data atau pencatatan data yang berulang.

\section{DISKUSI}

Penulis menyadari bahwa pada Sistem Informasi Akademik Siswa di SMKN 4 Payakumbuh ini masih memiliki beberapa kekurangan, untuk itu apabila penelitian ini ingin dilanjutkan, penulis ingin memberi beberapa saran mengenai bagian-bagian yang sebaiknya ditingkatkan, yaitu: 
1. Dalam tahap pengembangan selanjutnya, disarankan bagi peneliti untuk dapat menambahkan fasilitasfasilitas yang lebih lengkap seperti penjadwalan mata pelajaran.

2. Perlu adanya pengembangan dan pemeliharaan yang lebih baik lagi terhadap sistem yang telah dibuat, sehingga sistem dapat dipergunakan sesuai dengan kebutuhan.

\section{DAFTAR RUJUKAN}

Dian Kurniawan \& Sinta Verawati Dewi. 2017. Pengembangan Perangkat Pembelajaran Dengan Media Screencast-O-Matic Mata Kuliah Kalkulus 2 Menggunakan Model 4-D Thiagarajan. Jurnal Siliwangi, Vol, 3. No.1.

Muhammad Zakir \& Hari Antoni Musril. 2020. Perancangan Media Pembelajaran Produk Kreatif dan Kewirausahaan Berbasis Android di SMK Elektronika Indonesia Bukittinggi. Jurnal Edukasi Elektro, Vol 4, No. 2, pp. 153-157.

Z. Sesmiarni. 2011. Peranan Teknologi Pendidikan Dalam Peningkatan Mutu Pendidikan, Anal. J. Pendidik., Vol. 8, No. 2, pp. 109-121.

Iswantir. 2019. Pendidikan Islam Sejarah, Peran dan Kontribusi dalam Sistem Pendidikan Nasional. Bandar Lampung: CV. AURA.

W. Aprison. 2017. Filosofi Pendidikan Indonesia: Kajian Sumber Hukum Pendidikan, 1st ed. Bukittinggi: LP2M IAIN Bukittinggi.

M. Fadlillah. 2014. Implementasi Kurikulum 2013 dalam Pembelajaran SD/MI, SMP/MTS, \& SMA/MA, 1st ed. Yogyakarta: Ar-Ruzz Media.
A. N. Khomarudin \& L. Efriyanti. 2018. Pengembangan Media Pembelajaran Mobile Learning Berbasis Android Pada Mata Kuliah Kecerdasan Buatan. J. Educ. J. Educ. Stud., Vol. 3, No. 1, pp. $72-87$.

H. A. Musril, Jasmienti \& M. Hurrahman. 2020. Implementasi Teknologi Virtual Reality Pada Media Pembelajaran Perakitan Komputer. JANAPATI J. Nas. Pendidik. Tek. Inform., Vol. 9, pp. 8395.

T. Sutarti \& E. Irawan. 2017. Kiat-Kiat Sukses Meraih Hibah Penelitian Pengembangan, 1st ed. Yogyakarta: Deepublish.

R. R. Fadila, W. Aprison, \& H. A. Musril. 2019. Perancangan Perizinan Santri Menggunakan Bahasa Pemograman PHP / MySQL di SMP Nurul Ikhlas. CSRID J., Vol. 11, No. 2, pp. 84-95.

P. Setiawan, Sulistiowati, \& J. Lemantara. 2015. Rancang Bangun Aplikasi Pengolahan Data Evaluasi Proses Belajar Mengajar Berbasis Web Pada Stikes Yayasan RS. Dr. Soetomo Surabaya. Jsika, Vol. 4, No. 2, pp. 1-6.

T. S. Jaya. 2018. Pengujian Aplikasi dengan Metode Blackbox Testing Boundary Value Analysis (Studi Kasus: Kantor Digital Politeknik Negeri Lampung). J. Inform. Pengemb. IT, Vol. 3, No. 2, pp. $45-48$.

S. Christina, E. D. Oktaviyani, D. Ronaldo, \& R. M. Zaini. 2019. Aplikasi Absensi Siswa Berbasiskan Android. J. ELTIKOM, Vol. 3, No. 1, pp. 36-44.

A. Siswa, B. Sms, D. I. Smp, \& N. Surakarta. 2015. Pengembangan sistem informasi manajemen absensi siswa berbasis sms di smp negeri 14 surakarta. Naskah publikasi ilmiah. pp. 1-15. 